\title{
COMPARISON BETWEEN AUTOMATED SYSTEM AND PCR-BASED METHOD FOR IDENTIFICATION AND ANTIMICROBIAL SUSCEPTIBILITY PROFILE OF CLINICAL Enterococcus spp
}

Luciana FURLANETO-MAIA(1), Kátia Real ROCHA(2), Vera Lúcia Dias SIQUEIRA(3) \& Márcia Cristina FURLANETO(2)

\begin{abstract}
SUMMARY
Enterococci are increasingly responsible for nosocomial infections worldwide. This study was undertaken to compare the identification and susceptibility profile using an automated MicrosScan system, PCR-based assay and disk diffusion assay of Enterococcus spp. We evaluated 30 clinical isolates of Enterococcus spp. Isolates were identified by MicrosScan system and PCRbased assay. The detection of antibiotic resistance genes (vancomycin, gentamicin, tetracycline and erythromycin) was also determined by PCR. Antimicrobial susceptibilities to vancomycin $(30 \mu \mathrm{g})$, gentamicin $(120 \mu \mathrm{g})$, tetracycline $(30 \mu \mathrm{g})$ and erythromycin $(15 \mu \mathrm{g})$ were tested by the automated system and disk diffusion method, and were interpreted according to the criteria recommended in CLSI guidelines. Concerning Enterococcus identification the general agreement between data obtained by the PCR method and by the automatic system was $90.0 \%$ (27/30). For all isolates of E. faecium and E. faecalis we observed $100 \%$ agreement. Resistance frequencies were higher in E. faecium than E. faecalis. The resistance rates obtained were higher for erythromycin (86.7\%), vancomycin (80.0\%), tetracycline (43.35) and gentamicin (33.3\%). The correlation between disk diffusion and automation revealed an agreement for the majority of the antibiotics with category agreement rates of $>80 \%$. The PCR-based assay, the van(A) gene was detected in $100 \%$ of vancomycin resistant enterococci. This assay is simple to conduct and reliable in the identification of clinically relevant enterococci. The data obtained reinforced the need for an improvement of the automated system to identify some enterococci.
\end{abstract}

KEYWORDS: Enterococcus; MicrosScan system; PCR assay.

\section{INTRODUCTION}

Enterococci are implicated in a wide diversity of infections and are the third most common pathogen isolated from several infections worldwide ${ }^{35}$. According to a recent epidemiological survey conducted in Brazil, Enterococcus spp accounted for $4.5 \%$ of all nosocomial bloodstream infections (BSIs), resulting in $49.5 \%$ crude mortality $^{26}$.

Enterococci infections' greater mortality rates and antibiotic resistance are associated with prolonged hospitalization and increased health-care $\operatorname{costs}^{1,32}$. It has recently been reported that inappropriate and delayed antibiotic therapy present an independent risk factor for mortality caused by enterococcal bacteraemi ${ }^{36}$. Besides, the difficulty in treating enterococci infections, particularly with respect to vancomycin resistance isolates, emphasizes the need for safe and therapeutic guidance for rapid identification and effective management.

In this context, the employment of automated systems, that provide rapid identification and susceptibility testing, may lead to a significant reduction of patient morbidity, mortality and $\operatorname{cost}^{3}$. However, the identification and susceptibility testing of microorganisms usually takes
24-48 $\mathrm{h}$ after initial growth in a routine laboratory. In addition, automated systems may present problems in the identification of members of the genus Enterococcus in clinical laboratories ${ }^{11}$. Currently, several studies have compared the direct and standard methods for different automated systems $^{16,17,20,42}$

The employment of polymerase chain reaction (PCR)-based assay in the identification of enterococci and detection of antibiotic resistance genes offered a specific and rapid alternative to standard tests, providing essential information concerning the effective management and appropriate therapy of enterococcal bacteraemia ${ }^{10,14,21,41}$.

In this study, we compared for the first time the MicrosScan ${ }^{\circledR}$ system versus PCR-based approach for identification as well as the susceptibility profile of clinical Enterococcus sp.

\section{MATERIAL AND METHODS}

Isolates: A total of 30 Enterococcus clinical isolates were obtained from January 2008 to June 2010, from patients of the University Hospital of State University of Maringá (UEM). The origins of the isolates were

(1) Technological Federal University of Paraná, Brazil.

(2) Department of Microbiology, State University at Londrina, Paraná, Brazil.

(3) Department of Clinical Analysis, State University at Maringa, Paraná, Brazil.

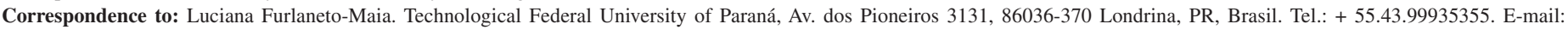
lucianamaia@utfpr.edu.br 
FURLANETO-MAIA, L.; ROCHA, K.R.; SIQUEIRA, V.L.D. \& FURLANETO, M.C. - Comparison between automated system and PCR-based method for identification and antimicrobial susceptibility profile of clinical Enterococcus spp. Rev. Inst. Med. Trop. Sao Paulo, 56(2): 97-103, 2014.

Table 1

Primers used in this study for identification of Enterococcus spp. and detection of different resistance genes by PCR-based method

\begin{tabular}{|c|c|c|c|c|}
\hline Gene & Nucleotide sequence $\left(5^{\prime}-3^{\prime}\right)^{\mathrm{a}}$ & $\mathrm{Ta} *\left({ }^{\circ} \mathrm{C}\right)$ & amplicon (bp) & References \\
\hline tuf & $\begin{array}{l}\text { TACTGACAAACCATTCATGATG } \\
\text { AACTTCGTCACCAACGCGAAC }\end{array}$ & 56 & 112 & 21 \\
\hline $\operatorname{van} C-1$ & $\begin{array}{l}\text { GGTATCAAGGAAACCTC } \\
\text { CTTCCGCCATCATAGCT }\end{array}$ & 56 & 822 & \multirow{4}{*}{10} \\
\hline $\begin{array}{l}\operatorname{van} C-2 \\
\operatorname{van} C-3\end{array}$ & $\begin{array}{l}\text { CTCCTACGATTCTCTTG } \\
\text { CGAGCAAGACCTTTAAG }\end{array}$ & 56 & 439 & \\
\hline$d d l_{E \text { faecalis }}$ & $\begin{array}{l}\text { ATCAAGTACAGTTAGTCT } \\
\text { ACGATTCAAAGCTAACTG }\end{array}$ & 56 & 941 & \\
\hline$d d l_{\text {Efaccium }}$ & $\begin{array}{l}\text { TAGAGACATTGAATATGCC } \\
\text { TCGAATGTGCTACAATC }\end{array}$ & 56 & 550 & \\
\hline $\operatorname{van} A$ & $\begin{array}{l}\text { GTAGGCTGCGATATTCAAAGC } \\
\text { CGATTCAATTGCGTAGTCCAA }\end{array}$ & 56 & $\begin{array}{l}231 \text { E. faecium } \\
330 \text { E. faecalis }\end{array}$ & 2 \\
\hline$a a c\left(6^{\prime}\right)-I e-a p h\left(2^{\prime \prime}\right)-I a$ & $\begin{array}{l}\text { CAGAGCCTTGGGAAGATGAAG } \\
\text { CCTCGTGTAATTCATGTTCTGGC }\end{array}$ & 56 & 348 & 39 \\
\hline $\operatorname{erm}(B)$ & $\begin{array}{l}\text { CATTTAACGACGAAACTGGC } \\
\text { GGAACATCTGTGGTATGGCG }\end{array}$ & 56 & 405 & \multirow{2}{*}{14} \\
\hline $\operatorname{tet}(L)$ & $\begin{array}{l}\text { GTMGTTGCGCGCTATATTCC } \\
\text { GTGAAMGRWAGCCACCTAA }\end{array}$ & 56 & 696 & \\
\hline
\end{tabular}

$\mathrm{Ta}\left({ }^{\circ} \mathrm{C}\right)=$ temperature of annealing/aM $=\mathrm{A}$ or $\mathrm{C} ; \mathrm{R}=\mathrm{A}$ or $\mathrm{G} ; \mathrm{W}=\mathrm{A}$ or $\mathrm{T} /(*)$ with modification/gene gene tuf, Enterococcus; vanC-1, E. gallinarum; vanC-2, vanC-3, E.casseliflavus, E. flavencens; tet(L), tetracycline; erm(B), erythromycin; aac(6')-aph(2')-Ia, gentamicin and vanA, vancomycin.

urine, blood, orotracheal fluid and rectal swab. The MicrosScan ${ }^{\circledR}$ was used in the identification of enterococci and in susceptibility test by using the standard growth detection algorithms provided by the system.

Isolation of enterococcal DNA, identification and detection of resistance genes by PCR: Enterococcus spp. genomic DNA was extracted by the boiling method as described by MARQUES \& SUZART $^{27}$. The identification of enterococci species was performed using a polymerase chain reaction (PCR) method. PCR assay was carried out using the following species-specific primers: $d d l_{E \text {.faecalis }}(E$. faecalis $), d d l_{E \text {.faecium }}(E$. faecium), vanC-1 (E. gallinarum), vanC-2 (E. casseliflavus) and vanC-3 (E. flavencens), and tuf for Enterococcus sp genus members (Table 1). The detection of resistance genes was conducted by PCR in all isolates of enterococci. The presence of gene vanA, aac(6')-Ie-aph(2')-Ia, $\operatorname{erm}(B)$ and $\operatorname{tet}(L)$, for vancomycin, gentamicin, erythromycin and tetracycline, respectively (Table 1).

All PCR amplifications were performed in a final volume of $20 \mu \mathrm{L}$ containing one pmol of each primer (Forward and Reverse), $0.17 \mathrm{mM}$ dNTPs, $2.5 \mathrm{mM} \mathrm{MgCl}_{2}$, one U of Taq DNA polymerase (Invitrogen), buffer of Taq, and $10 \mu \mathrm{L}$ template DNA. An initial cycle of denaturation $\left(94{ }^{\circ} \mathrm{C}\right.$ for two min), was followed by 30 cycles of denaturation $\left(94^{\circ} \mathrm{C}\right.$ for one $\mathrm{min}$ ), annealing at an appropriate temperature for one min and elongation ( $72{ }^{\circ} \mathrm{C}$ for $10 \mathrm{~min}$ ). A Thermal Cycler (Techne-Tc3000) was used to carry out the PCR reactions. PCR products were analyzed by gel electrophoresis in $1.5 \%$ agarose stained with ethidium bromide ( 0.5 g.mL-1), observed under UV transillumination and photographed by L-PIX ST (LOCCUS).

Antimicrobial susceptibility testing: Susceptibility testing of four antimicrobial agents (vancomycin, $30 \mu \mathrm{g}$; tetracycline, $30 \mu \mathrm{g}$; erythromycin, $15 \mu \mathrm{g}$; and gentamicin $120 \mu \mathrm{g}$ ) (Laborclin) was performed by the disk diffusion assay on Muller Hinton agar plates. After 18 or 24 $\mathrm{h}$ of incubation at $37{ }^{\circ} \mathrm{C}$, inhibition zone diameters around each disc were measured and the diameters of inhibition zones were interpreted according to the criteria recommended by the Clinical and Laboratory Standards Institute, 2011. Staphlylococccus aureus 25923 ATCC was used as a control strain. MicrosScan ${ }^{\circledR}$ system was used on the same antimicrobial agents for the antimicrobial susceptibility testing.

\section{RESULTS}

In the present study, we firstly evaluated the genetic similarities of the Enterococcus isolates using the RAPD-PCR analysis. The fingerprinting revealed no clonal lineage (unrelated strains) among tested isolates (data not shown).

As shown in Table 2, for 27 out of $30(90 \%)$ isolates the identification was concordant between the automated system and the molecular method. All 20 isolates identified as E. faecium and seven isolates as E. faecalis by automation system were confirmed by PCR assay. Figure 1 illustrated the amplicon size of Enterococcus sp. Among the isolates tested, E. faecium $(76.7 \%$ ) had a much higher incidence rate followed by E. faecalis $(23.3 \%)$.

The disagreement was observed in the identification of three isolates. The species classified by automation as E. gallinarum (isolate 817 ) and E. durans/hirae (isolate 917 and 1000) were all identified as E. faecium by the PCR assay. 


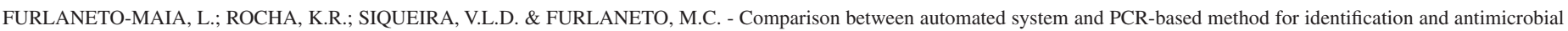
susceptibility profile of clinical Enterococcus spp. Rev. Inst. Med. Trop. Sao Paulo, 56(2): 97-103, 2014.

Table 2

Identification of clinical enterococci isolates by automated systems and molecular method

\begin{tabular}{|c|c|c|c|}
\hline \multirow{2}{*}{ Strain } & \multirow{2}{*}{ origin } & \multicolumn{2}{|c|}{ Identification } \\
\hline & & automated system & PCR-based assay \\
\hline 802 & urine & E. faecalis & E. faecalis \\
\hline 817 & rectal swab & E. gallinarum & E. faecium \\
\hline 840 & blood & E. faecalis & E. faecalis \\
\hline 848 & urine & E. faecalis & E. faecalis \\
\hline 872 & orotracheal fluid & E. faecalis & E. faecalis \\
\hline 906 & urine & E. faecalis & E. faecalis \\
\hline 917 & urine & E. durans/hirae & E. faecium \\
\hline 924 & rectal swab & E. faecium & E. faecium \\
\hline 925 & rectal swab & E. faecium & E. faecium \\
\hline 928 & urine & E. faecalis & E. faecalis \\
\hline 973 & urine & E. faecium & E. faecium \\
\hline 1000 & urine & E. durans/hirae & E. faecium \\
\hline 1035 & rectal swab & E. faecium & E. faecium \\
\hline 1053 & rectal swab & E. faecium & E. faecium \\
\hline 1062 & rectal swab & E. faecium & E. faecium \\
\hline 1076 & rectal swab & E. faecium & E. faecium \\
\hline 1097 & rectal swab & E. faecium & E. faecium \\
\hline 1112 & rectal swab & E. faecium & E. faecium \\
\hline 1114 & rectal swab & E. faecium & E. faecium \\
\hline 1115 & rectal swab & E. faecium & E. faecium \\
\hline 1125 & rectal swab & E. faecium & E. faecium \\
\hline 1143 & rectal swab & E. faecium & E. faecium \\
\hline 1211 & urine & E. faecalis & E. faecalis \\
\hline 1215 & rectal swab & E. faecium & E. faecium \\
\hline 1227 & urine & E. faecium & E. faecium \\
\hline 1231 & urine & E. faecium & E. faecium \\
\hline 1246 & urine & E. faecium & E. faecium \\
\hline 1280 & rectal swab & E. faecium & E. faecium \\
\hline 1295 & rectal swab & E. faecium & E. faecium \\
\hline 1298 & rectal swab & E. faecium & E. faecium \\
\hline
\end{tabular}

Antibiotic susceptibility phenotypes and resistance genes profile, detected by PCR, of the enterococcal isolates are shown in Table 3. The presence of resistance genes $\operatorname{erm}(B), \operatorname{tet}(L), \operatorname{vanA}$ and $\operatorname{aac}\left(6^{\prime}\right)-\operatorname{Ie}$ - $\operatorname{aph}\left(2^{\prime \prime}\right)$ were $86.7 \%, 23.3 \%, 80.0 \%$ and $66.7 \%$, respectively. Several isolates harbored resistance genes to more than one antibiotic. Of significance were $\operatorname{tet}(L)^{+} / \mathrm{erm}(B)^{+}$to E. faecalis $(42.8 \%)$ and $\mathrm{erm}(B)^{+} / \mathrm{aac}\left(6^{\prime}\right)$-Ie$\operatorname{aph}(2 ")-\mathrm{Ia}^{+} / \mathrm{vanA}^{+}$to E. faecium $(69.6 \%)$.

The presence of the vanA gene was detected in three isolates of $E$. faecalis and twenty-two of E. faecium, corresponding to $42.8 \%$ and $96.6 \%$ of the isolates, respectively. The $\operatorname{van}(A)$ gene was detected in $100 \%$ of vancomycin resistant enterococci (Table 3), however, five isolates harbored the $\operatorname{van}(A)$ gene and presented vancomycin susceptibility phenotype.

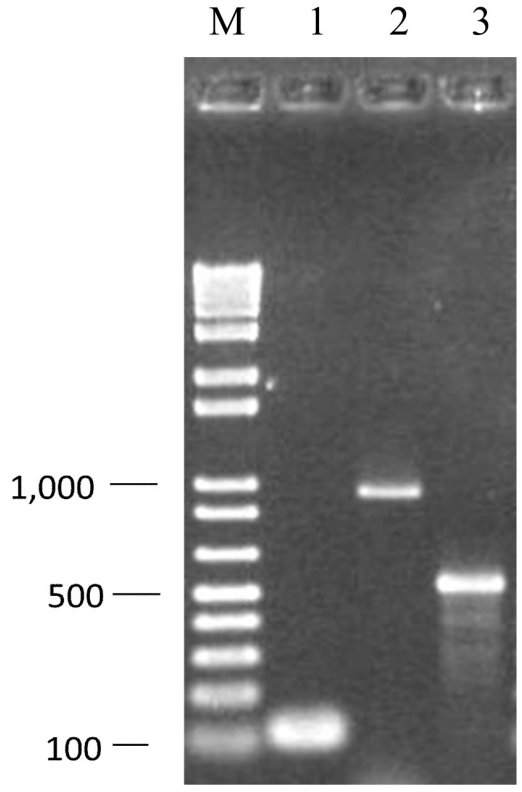

Fig. 1 - Amplification gel pictures characteristic of polymerase chain reaction (PCR) amplification of Enterococcus sp gene. Lanes: (1) Enterococcus spp. (112 pb), (2) E. faecalis (941 pb), (3) E. faecium (550 pb). M - Ladder 1kb plus (Invitrogen).

On the other hand, antimicrobial resistance phenotype was detected even in the absence of the respective resistance gene for two isolates to $\operatorname{erm}(B), 10$ to $\operatorname{tet}(L)$ and three to $\operatorname{aac}\left(6^{\prime}\right)$-Ie-aph(2”)-Ia gene.

Additionally, antimicrobial susceptibilities to erythromycin, tetracyclin, vancomycin, and gentamicin were analyzed by disk diffusion. Evaluation revealed excellent agreement for all of the antibiotics with category agreement rates $>80 \%$ between automatized method and disk diffusion. Major error rates were for erythromycin, vancomycin and tetracycline with $20.7 \%, 7 \%$ and $16.7 \%$ respectively. Minor error rates were found as $12.1 \%$ for gentamicin.

Resistance rates obtained by disc diffusion were as follows: $86.7 \%$ for erythromycin, $80.0 \%$ for vancomycin, $43.35 \%$ for tetracycline and $33.3 \%$ for gentamicin. Resistance frequencies were higher in E. faecium than E. faecalis.

\section{DISCUSSION}

Enterococci have been implicated in severe human infections as a consequence of associated determinants of virulence and antimicrobial resistance. Accurate identification and rapid analysis of the antibiotic susceptibility pattern of the causative microbial agent leads to earlier targeting of antibiotic therapy and may be lifesaving.

In this study, we describe a comparison between automatic and PCRbased assay for identification of Enterococcus spp. Our results showed $90 \%$ agreement in the identification of clinically relevant enterococcal species, revealing that the PCR method is reliable and convenient for rapid identification and has potential for use in clinical microbiology laboratories.

Besides, one isolate was identified as E. gallinarum and two were 


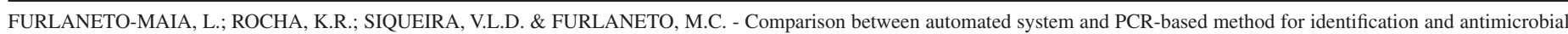
susceptibility profile of clinical Enterococcus spp. Rev. Inst. Med. Trop. Sao Paulo, 56(2): 97-103, 2014.

Table 3

PCR presence/absence assays of various antibiotic resistance genes for Enterococcus and antibiotic resistant phenotypes by automated systems

\begin{tabular}{|c|c|c|c|c|c|c|c|c|}
\hline \multirow{2}{*}{ Isolates } & \multicolumn{4}{|c|}{ Genes detected by PCR } & \multicolumn{4}{|c|}{ Antibiotic resistance phenotype (MIC $\mu \mathrm{g} / \mathrm{mL})^{*}$} \\
\hline & $e m(B)$ & $\operatorname{tet}(L)$ & vanA & $a a c\left(6^{\prime}\right)-I e-a p h\left(2^{\prime}\right)-I a$ & ERY & TET & VAN & GEN \\
\hline 802 & + & + & + & - & $>4 \mathrm{R}$ & $>8 \mathrm{R}$ & $\leq 2 \mathrm{~S}$ & $\leq 500 \mathrm{~S}$ \\
\hline 817 & - & - & + & + & $\leq 0,5 \mathrm{~S}$ & $>8 \mathrm{R}$ & $8 \mathrm{I}$ & $\leq 500 \mathrm{~S}$ \\
\hline 840 & - & - & + & - & $>4 \mathrm{R}$ & $\leq 4 \mathrm{~S}$ & $\leq 2 \mathrm{~S}$ & $\leq 500 \mathrm{~S}$ \\
\hline 848 & + & + & - & - & 2 & $\leq 4 \mathrm{~S}$ & $\leq 2 \mathrm{~S}$ & $\leq 500 \mathrm{~S}$ \\
\hline 872 & + & + & - & - & $>4 \mathrm{R}$ & $>8 \mathrm{R}$ & $\leq 2 \mathrm{~S}$ & $\leq 500 \mathrm{~S}$ \\
\hline 906 & + & + & - & - & $>4$ & $>8 \mathrm{R}$ & $\leq 2 \mathrm{~S}$ & $\leq 500 \mathrm{~S}$ \\
\hline 917 & + & + & - & - & $>4$ & $>8 \mathrm{R}$ & $\leq 2 \mathrm{~S}$ & $\leq 500 \mathrm{~S}$ \\
\hline 924 & + & - & + & + & $>4$ & $\leq 4 \mathrm{~S}$ & $>16 \mathrm{R}$ & $\leq 500 \mathrm{~S}$ \\
\hline 925 & + & + & + & + & $>4$ & $\leq 4 \mathrm{~S}$ & $>16 \mathrm{R}$ & $\leq 500 \mathrm{~S}$ \\
\hline 928 & + & - & + & + & $--/ /--$ & $>8 \mathrm{R}$ & $\leq 2 \mathrm{~S}$ & --//-- \\
\hline 973 & + & - & + & + & $>4$ & $>8 \mathrm{R}$ & $\leq 2 \mathrm{~S}$ & --//-- \\
\hline 1000 & + & - & + & + & $>4$ & $\leq 4 \mathrm{~S}$ & $>16 \mathrm{R}$ & $>500 \mathrm{R}$ \\
\hline 1035 & + & - & + & + & $>4$ & $>8 \mathrm{R}$ & $>16 \mathrm{R}$ & $>500 \mathrm{R}$ \\
\hline 1053 & + & - & + & + & $>4$ & $>8 \mathrm{R}$ & $>16 \mathrm{R}$ & $\leq 500 \mathrm{~S}$ \\
\hline 1062 & + & - & + & + & $>4$ & $\leq 4 \mathrm{~S}$ & $>16 \mathrm{R}$ & $>500 \mathrm{R}$ \\
\hline 1076 & + & - & + & + & $>4$ & $>8 \mathrm{R}$ & $>16 \mathrm{R}$ & $\leq 500 \mathrm{~S}$ \\
\hline 1097 & - & - & + & + & $>4$ & $>8 \mathrm{R}$ & $>16 \mathrm{R}$ & $\leq 500 \mathrm{~S}$ \\
\hline 1112 & + & - & + & - & $>4$ & $\leq 4 \mathrm{~S}$ & $>16 \mathrm{R}$ & $>500 \mathrm{R}$ \\
\hline 1114 & + & - & + & + & $>4$ & $\leq 4 \mathrm{~S}$ & $>16 \mathrm{R}$ & $>500 \mathrm{R}$ \\
\hline 1115 & + & - & + & - & $>4$ & $\leq 4 \mathrm{~S}$ & $>16 \mathrm{R}$ & $>500 \mathrm{R}$ \\
\hline 1125 & + & + & + & + & $>4$ & $\leq 4 \mathrm{~S}$ & $>16 \mathrm{R}$ & $>500 \mathrm{R}$ \\
\hline 1143 & + & - & + & - & $>4$ & $\leq 4 \mathrm{~S}$ & $>16 \mathrm{R}$ & $>500 \mathrm{R}$ \\
\hline 1211 & - & - & - & - & $\leq 0,5$ & $\leq 4 \mathrm{~S}$ & $\leq 2 \mathrm{~S}$ & $\leq 500 \mathrm{~S}$ \\
\hline 1215 & + & - & + & + & $>4 \mathrm{R}$ & $>8 \mathrm{R}$ & $>16 \mathrm{R}$ & $\leq 500 \mathrm{~S}$ \\
\hline 1227 & + & - & + & + & $>4$ & $\leq 4 \mathrm{~S}$ & $>16 \mathrm{R}$ & $>500 \mathrm{R}$ \\
\hline 1231 & + & - & + & + & $>4$ & $>8 \mathrm{R}$ & $>16 \mathrm{R}$ & $\leq 500 \mathrm{~S}$ \\
\hline 1246 & + & - & + & + & $>4$ & $\leq 4 \mathrm{~S}$ & $>16 \mathrm{R}$ & $>500 \mathrm{R}$ \\
\hline 1280 & + & - & + & + & $>4 \mathrm{R}$ & $\leq 4 \mathrm{~S}$ & $>16 \mathrm{R}$ & $>500 \mathrm{R}$ \\
\hline 1295 & + & - & + & + & $>4 \mathrm{R}$ & $\leq 4 \mathrm{~S}$ & $>16 \mathrm{R}$ & $>500 \mathrm{R}$ \\
\hline 1298 & + & - & + & + & $>4 \mathrm{R}$ & $>8 \mathrm{R}$ & $>16 \mathrm{R}$ & $\leq 500 \mathrm{~S}$ \\
\hline
\end{tabular}

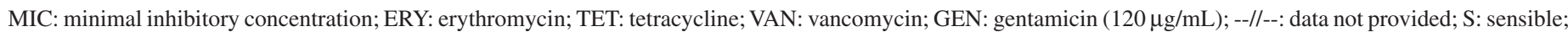
R: resistance; I: intermediate resistance. (*) Result obtained from the automated method. 


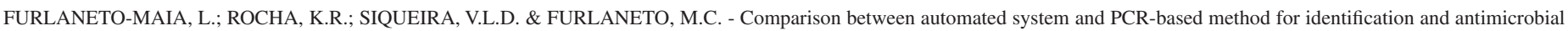
susceptibility profile of clinical Enterococcus spp. Rev. Inst. Med. Trop. Sao Paulo, 56(2): 97-103, 2014.

identified as E. durans/hirae by MicrosScan, whereas by PCR-based assay all three isolates were identified as E. faecium. Similar discrepancy was described by ROBREDO et $_{\text {al. }}{ }^{30}$, who compared the API20 STREP and colony hybridization for identification of enterococci obtained from several origins. According to these authors, high agreement was obtained for E. faecalis identification, however, for eight isolates identified as E. durans and E. casseliflavus by API20 STREP were identified as E. faecium according to the molecular method.

Several studies have found differences between automatic and classical or molecular bacterial identification systems. For instance, concerning Gram positive bacteria, no gram-positive cocci showed concordant identification between the direct and standard methods; other discrepancies consisted of misidentification between various species of coagulase-negative staphylococci ${ }^{7}$.

On the other hand, some studies showed the agreement between automatic and classical or molecular bacterial identification systems ${ }^{16,33}$. D'AZEVEDO et al. ${ }^{9}$ compared the automated Vitek system and standard methods for identification of 80 isolates belonging to different species of Enterococcus. The general agreement between results was $83.7 \%$. Among isolates of E. faecalis and E faecium were observed that the automated system correctly identified 35/40 (87.5\%) and 12/14 (85.7\%) of the strains, respectively?.

CEKIN et al. ${ }^{4}$ demonstrated the consistency of automated systems with the conventional methods. They detected as $97.8 \%$ to identification of VRE strains using both methods.

Based on the results presented here and the previous report ${ }^{39}$ there is a need for improvement in the automated MicrosScan system to identify enterococci.

In the present study, the genotypic basis of the resistance phenotype found in isolates of E. faecium and E. faecalis was investigated by PCR based detection of resistance genes. The majority of Enterococcus isolates displayed resistance to at least one antibiotic tested. Our results revealed that the vanA gene was predominant in E. faecium tests since this gene was detected in $100 \%$ of vancomycin-resistant isolates, although Enterococcus spp. may harbor other genes (vanB, vanC-1, vanC-2/3 and vanD) related to resistance ${ }^{37}$.

Antibiotic resistance has played an essential role in the emergence of E. faecalis and E. faecium as nosocomial pathogens. Vancomycin is an important therapeutic option for the treatment of severe enterococcal infections and resistance to this type of antibiotic is concerning. Identified risk factors for vancomycin-resistant enterococci (VRE) acquisition include a prolonged hospital stay, exposure to intensive care units or residence on transplant oncology wards, prior exposure to antibiotics, and proximity to other patients infected or colonized with $\mathrm{VRE}^{40}$.

In our study we detected the $\operatorname{tet}(L)$ gene in $23.3 \%$ (7/30) of the isolates, while four and five of these presented resistance to tetracycline in automated and disk diffusion method, respectively. Similar prevalence of tet $(L)$ gene $(21 \%)$ in enterococci was described by STOVCIK et al. ${ }^{35}$. In contrast, FRAZZON et al. ${ }^{13}$ detected the $\operatorname{tet}(L)$ gene in only $9 \%$ of the Enterococcus sp isolates. Furthermore, tetracycline resistance phenotype was detected even in the absence of the tet $(L)$ gene for 10 isolates. This may be explained by the fact that in enterococci two major groups of tetracycline resistance genes have been identified. One group encoding ribosomal protection proteins include $\operatorname{tet}(M), \operatorname{tet}(O)$ and tet $(S)$ genes, and the another one that encodes tetracycline efflux pumps proteins include the $\operatorname{tet}(L)$ and $\operatorname{tet}(K)$ genes $^{18,22,28}$. Similarly, erythromycin resistance was detected even in the absence of the $\operatorname{erm}(B)$ gene. This resistance may be due to the presence of $\operatorname{erm}(A$ and/or $\operatorname{erm}(C))$ genes related to erythromycin resistance phenotype ${ }^{37}$.

Gentamicin susceptible phenotype was detected in $36.7 \%$ of the isolates. However, $52.6 \%$ of these were detected as the aac(6')-Ie$a p h\left(2\right.$ ")-Ia gene. Similar results were obtained by POULSEN et al. ${ }^{29}$.

In our study, the MicrosScan system and disk diffusion method had an agreement of about $80 \%$. GÜLMEZ \& HASÇELIK ${ }^{16}$ compared the Phoenix system and microdilution method and observed an excellent agreement for all of the antibiotics with category agreement rates of $>$ $97 \%$. In contrast, the API method was considered unreliable in detecting high levels of aminoglycoside resistance among Enterococcus strains compared to disc diffusion method ${ }^{34}$.

Our data revealed high frequency of E. faecium and the occurrence of several multi resistance isolates. Antibiotic resistance appears to have contributed to increasing administration of inadequate antimicrobial therapy for infections, particularly enterococci nosocomial acquired infections, which is associated with greater hospital mortality rates ${ }^{5,23}$.

Rapid and reliable identification of these antibiotic resistant organisms is crucial for patient management and infection control measures. Enterococci are intrinsically resistant to many antimicrobial agents, and their ability to acquire resistance to other agents such as aminoglycosides, $\beta$-lactams and glycopeptides (vancomycin and teicoplanin) is well known, resulting in invasive human enterococcal infections that are extremely difficult to treat.

The primary objective of the study was to determine whether molecular identification and direct antimicrobial susceptibility testing would provide results comparable to those obtained from an automated system in routine use. This study revealed that the PCR assay and disk diffusion method are in agreement with MicroScan automated system employed for identification and test susceptibility, respectively of clinical Enterococcus spp.

\section{RESUMO}

\section{Comparação entre o sistema automatizado e PCR na identificação e susceptibilidade de isolados clínicos de Enterococcus spp}

Os enterococos são cada vez mais responsáveis por infecções hospitalares em todo o mundo. Este estudo foi realizado para comparar a identificação e perfil de suscetibilidade entre o sistema automatizado MicrosScan e a técnica molecular de PCR em espécies de Enterococcus spp. Foram avaliados 30 isolados clínicos de Enterococcus spp. Os isolados foram identificados pelo sistema MicrosScan ${ }^{\circledR}$ e pela técnica de PCR. A detecção de genes de resistência a antibióticos (vancomicina, gentamicina, tetraciclina e eritromicina) foi determinada por PCR. Suscetibilidades antimicrobianas à vancomicina $(30 \mu \mathrm{g})$, gentamicina $(120 \mu \mathrm{g})$, tetraciclina $(30 \mu \mathrm{g})$ e eritromicina $(15 \mu \mathrm{g})$, foram testados 
FURLANETO-MAIA, L.; ROCHA, K.R.; SIQUEIRA, V.L.D. \& FURLANETO, M.C. - Comparison between automated system and PCR-based method for identification and antimicrobial susceptibility profile of clinical Enterococcus spp. Rev. Inst. Med. Trop. Sao Paulo, 56(2): 97-103, 2014

pelos métodos automatizados e pelo disco difusão, de acordo com as orientações do CLSI. No que diz respeito à identificação de Enterococcus em geral entre os dados obtidos pelo método de PCR e pelo sistema automático foi de 90,0\% (27/30). Para todos os isolados de E. faecium e E. faecalis observamos concordância de $100 \%$. Freqüências de resistência foi maior em E. faecium do que em E. faecalis. As taxas de resistência obtidas foi maior para eritromicina $(86,7 \%)$, vancomicina $(80,0 \%)$, tetraciclina $(43,35 \%)$ e gentamicina $(33,3 \%)$. A correlação entre a técnica de disco difusão e automação revelou-se de acordo para maioria dos antibióticos com taxas $>80 \%$. O gene $\operatorname{van}(\mathrm{A})$ foi detectado em $100 \%$ dos Enterococcus resistentes á vancomicina. O ensaio baseado em PCR é de simples realização e de confiança para identificação de enterococos clinicamente relevantes. Os dados obtidos reforçam a necessidade de melhoria no sistema automatizado para identificar alguns enterococos.

\section{ACKNOWLEDGEMENT}

This work was supported by Conselho Nacional de Desenvolvimento Científico e Tecnológico (CNPq) - Brazil and Fundação Araucária Paraná, Brazil. Kátia Real Rocha is fellowship holder of Coordenação de Aperfeiçoamento de Pessoal de Nível Superior (CAPES) - Brazil.

\section{CONFLICT OF INTEREST}

The authors have no conflict of interest to declare.

\section{REFERENCES}

1. Acar JF. Consequences of bacterial resistance to antibiotics in medical practice. Clin Infect Dis.1997;24(suppl 1):S17-8.

2. Bell IM, Paton JC, Turnidge J. Emergence of vancomycin-resistant enterococci in Australia: phenotypic and genotypic characteristics of isolates. J Clin Microbiol. 1998;36:2187-90.

3. Bruins MJ, Bloembergen P, Ruijs GJHM, Wolfhagen MJHM. Identification and susceptibility testing of Enterobacteriaceae and Pseudomonas aeruginosa by direct inoculation from positive BACTEC blood culture bottles into Vitek 2. J Clin Microbiol. 2004;42:7-11.

4. Cekin Y, Ozhak Baysan B, Mutlu D, Sepin Özen N, Öngut G, Dönmez L, et al. Comparison of Phoenix automated system, API ID 32 Strep system and lightcycler Enterococcus MGRADE system in the identification of clinical Enterococcus isolates. Mikrobiyol Bul. 2013;47:141-6

5. Chow JW, Fine MJ, Shlaes DM, Quinn JP, Hooper DC, Johnson MP, et al. Enterobacter bacteremia: clinical features and emergence of antibiotic resistance during therapy. Ann Int Med. 1991;115: 585-90.

6. CLSI-Clinical and Laboratory Standards Institute. Performance Standards for Antimicrobial Susceptibility Testing; Twenty-First Informational Supplement Approved standard M100-S21, v. 31, 2011. Wayne; 2011.

7. Courvalin P. Vancomycin resistance in gram-positive cocci. Clin Infect Dis. 2006;42(Suppl 1):S25-S34.

8. Cueto M, Ceballos E, Martinez-Martinez L, Perea EJ, Pascua A. Use of positive blood cultures for direct identification and susceptibility testing with the Vitek 2 system. J Clin Microbiol. 2004;42:3734-8.

9. D 'Azevedo PA, Cantarelli V, Inamine E, Superti S, Dias CAG. Avaliação de um sistema automatizado na identificação de espécies de Enterococcus. J Bras Patol Med Lab. 2004;40;237-9.
10. Dukta-Malen S, Evers S, Courvalin P. Detection of glycopeptide resistance genotypes and identification to the species level of clinically relevant enterococci by PCR. J Clin Microbiol. 1995;33:24-7.

11. Facklam RR, Sahm D, Teixeira LM. Enterococcus. In: Murray PR, Baron EJ, Pfaller MA, Tenover FC, Yolken RH, editors. Manual of Clinical Microbiology. 7. ed. Washington: ASM Press; 1999. p. 297-305.

12. Fontanals D, Salceda F, Hernandez J, Sanfeliu I, Torra DM. Evaluation of wider systems for direct identification and antimicrobial susceptibility testing of gramnegative bacilli from positive blood culture bottles. Eur J Clin Microbiol Infect Dis. 2002;21:693-5.

13. Frazzon APG, Gama BA, Hermes V, Bierhals CG, Pereira RI, Guedes AG, et al. Prevalence of antimicrobial resistance and molecular characterization of tetracycline resistance mediated by $\operatorname{tet}(M)$ and tet $(L)$ genes in Enterococcus spp. isolated from food in Southern Brazil. World J Microbiol Biotechnol. 2010; 2:365-70.

14. Gevers D, Danielsen M, Huys G, Swings J. Molecular characterization of $\operatorname{tet}(M)$ genes in Lactobacillus isolates from different types of fermented dry sausage. Appl Environ Microbiol. 2003;69:1270-5.

15. Gholizadeh Y, Courvalin P. Acquired and intrinsic glycopeptide resistance in enterococci. Int J Antimicrob Agents. 2000;16(Suppl 1):S11-7.

16. Gülmez D, Hasçelik G. Comparison of microdilution method and Phoenix automated system for testing antimicrobial susceptibilities of Enterococcus strains. Mikrobiyol Bul. 2011;45:21-7.

17. Hansen DS, Jensen AG, Norskov-Lauritsen N, Skov R, Bruun B. Direct identification and susceptibility testing of enteric bacilli from positive blood cultures using VITEK (GNI/GNS-GA). Clin Microbiol Infect. 2002;8:38-44.

18. Huys G, D’Haene K, Collard JC, Swings J. Prevalence and molecular characterization of tetracycline resistance in Enterococcus isolates from food. Appl Environ Microbiol. 2004;70:1555-62.

19. Jensen LB, Ahrens P, Dons L, Jones RN, Hammerum AM, Aarestrup FM. Molecular analysis of the Tn 1546 in Enterococcus faecium isolated from animals and humans. J Clin Microbiol. 1998;36:437-42.

20. Jin WY, Jang SJ, Lee MJ, Park G, Kim MJ, Kook JK, et al. Evaluation of VITEK 2 , MicroScan, and Phoenix for identification of clinical isolates and reference strains. Diag Microbiol Infect Dis. 2011;70:442-7.

21. Ke D, Picard FJ, Martineau F, Ménard PHR, Ouellette M, Bergeron MG. Developmen of a PCR assay for rapid detection of enterococci. J Clin Microbiol. 1999;37:3497503.

22. Kobashi Y, Hasebe A, Nishio M, Uchiyama H. Diversity of tetracycline resistance genes in bacterial isolated from various agricultural environmental. Microbes Environment. 2007;22:44-51.

23. Leibovici L, Shraga I, Drucker M, Konigsberger H, Samra Z, Pitlik SD. The benefit of appropriate empirical antibiotic treatment in patients with bloodstream infection. J Int Med. 1998;244:379-86.

24. Linden PK. Clinical implications of nosocomial Gram-positive bacteremia and superimposed antimicrobial resistance. Am J Med. 1998;104(5A):24-33.

25. Lupetti S, Barnini B, Castagna B, Nibbering PH, Campa M. Rapid identification and antimicrobial susceptibility testing of Gram-positive cocci in blood cultures by direct inoculation into the BD Phoenix system. Clin Microbiol Infect. 2010;16:986-91.

26. Marra AR, Camargo LFA, Pignatari ACC, Sukiennik T, Behar PR, Medeiros EA, et al. Nosocomial bloodstream infections in Brazilian Hospitals: analysis of 2,563 cases from a prospective nationwide surveillance study. J Clin Microbiol 2011;49:1866-71. 
FURLANETO-MAIA, L.; ROCHA, K.R.; SIQUEIRA, V.L.D. \& FURLANETO, M.C. - Comparison between automated system and PCR-based method for identification and antimicrobial susceptibility profile of clinical Enterococcus spp. Rev. Inst. Med. Trop. Sao Paulo, 56(2): 97-103, 2014.

27. Marques EB, Suzart S. Occurrence of virulence-associated genes in clinical Enterococcus faecalis strains isolated in Londrina, Brazil. J Med Microbiol. 2004;53:1069-73.

28. Poeta P, Costa D, Sáenz N, Klibi N, Ruiz-Larrea F, Rodrigues J, et al. Characterization of antibiotic resistance genes and virulence factors in faecal enterococci of wild animals in Portugal. J Vet Med B Infect Dis Vet Public Health. 2005;52:396-402.

29. Poulsen L, Bisgaard M, Son NT, Trung NV, An HM, Dalsgaard A. Enterococcus and Streptococcus spp. associated with chronic and self-medicated urinary tract infections in Vietnam. BMC Infect Dis. 2012,12:320.

30. Ratanasuwan W, Iwen PC, Hinrichs SH, Rupp ME. Bacteremia due to motile Enterococcus species: clinical features and outcomes. Clin Infect Dis. 1999;28:1175-7.

31. Robredo B, Singh KV, Baquero F, Murray BE, Torres C. Vancomycin-resistant enterococci isolated from animals and food. Int J Microbiol. 2000;54:197-204

32. Rubin RJ, Harrington CA, Poon A, Diretrich K, Greene A, Moiduddin A. The economic impact of Staphylococcus aureus infection in New York city hospitals. Emerg Infect Dis. 1999;5:9-17.

33. Seo JY, Kim PW, Lee JH, Song JH, Peck KR, Chung DR, et al. Evaluation of PCR based screening for vancomycin-resistant enterococci compared with a chromogenic agar-based culture method. J Med Microbiol. 2011;60:945-9.

34. Sirin MC, Adiloğlu AK. Comparison of five antimicrobial susceptibility tests in detecting high level aminoglycoside and vancomycin resistances in hospital acquired Enterococcus isolates. Clin Lab. 2011;57:157-62.

35. Stovcik V, Javorsky P, Pristas P. Antibiotic resistance patterns and resistance genes in enterococci isolated from sheep gastrointestinal tract in Slovakia. Bull Vet Inst Pulawy. 2008;52:53-7.

36. Suppli M, Aabenhus R, Harboe ZB, Andersen LP, Tvede M, Jensen J-US. Mortality in enterococcal bloodstream infections increases with inappropriate antimicrobial therapy. Clin Microbiol Infect. 2011;17:1078-83.
37. Torres C, Escobar S, Portillo A, Torres L, Rezusta A, Ruiz-Larrea F, et al. Detection of clonally related vanB2- containing Enterococcus faecium strains in two Spanish hospitals. J Med Microbiol. 2006;55:1237-43.

38. Top J, Willens R, Bonten M. Emergence of CC17 Enterococcus faecium: from commensal to hospital-adapted pathogen. FEMS Immunol Med Microbiol. 2008;52:297-308

39. Tritz DM, Iwen PC, Woods GL. Evaluation of MicroScan for identification of Enterococcus species. J Clin Microbiol. 1990;28:1477-8.

40. Usacheva EA, Ginocchio CC, Morgan M, Maglanoc G, Mehta MS, Tremblay S, et al. Prospective, multicenter evaluation of the BD gene Ohm vanR assay for direct, rapid detection of vancomycin- resistant Enterococcus species in perianal and rectal specimens. Am J Clin Pathol. 2010;134:219-26.

41. Vakulenko SB, Donabedian SM, Vorkresenskiy AM, Zervos MJ, Lerner SA, Chow JW. Multiplex PCR for detection of aminoglycoside resistance genes in enterococci. Antimicrob Agents Chemother. 2003;47:1423-6.

42. Waites KB, Brookings ES, Moser SA, Zimmer DBL. Direct susceptibility testing with positive BacT/Alert blood cultures by using Micro-Scan overnight and rapid panels. J Clin Microbiol. 1998;36:2052-6.

43. Werner G, Coque TM, Hammerum AM, Hope R, Hryniewicz W, Johnson A, et al Emergence and spread of vancomycin resistance among enterococci in Europe. Euro Surveill. 2008;13:1-11

44. Willey BM, Jones RN, McGeer A, Witte W, French G, Roberts RB, et al. Practica approach to the identification of clinically relevant Enterococcus species. Diag Microbiol Infect Dis. 1999;34:165-71

Received: 5 November 2012

Accepted: 5 September 2013 